\section{OP-221難治性精巣腫瘍に対する化学療法の現 況}

\section{新潟大学医歯学総合研究院生体機能調節医学専攻機能再 建医学講座腎泌尿器病態学分野}

新井 啓, 若月 俊二, 谷川 俊貴, 西山 勉, 高橋 公太 【はじめに】難治性精巣腫揚に対して当科では超大量化学 療法をサルベージ療法として行ってきた。しかし諸家の 報告では超大量化学療法の CR 率は $10 \sim 40 \%$ 程度にと どまっている。今回我々は新規抗癌剤パクリタキセル (TXL)、イリノテカノン (CPT-11) を用い、難治再発症 例に対するサルベージ療法を行った。【対象、方法】標 準量化学療法、超大量化学療法後の難治再発例 7 例に対 し 2nd line、3rd line として TIP 療法 (TXL、ifosfamide、 CDDP)、CPT-11/NDP 療法 (CPT-11、nedaplatin) を行っ た。【結果】標準化学療法後、2nd line として TIP 療法を 行った 3 例中 2 例が PR、1 例が CR。2nd line に TIP 療 法、3rd line にCPT-11/NDP 療法を行った 1 例は CR であった。超大量化学療法後 2nd lineにTXL、epirubicin、CDDP 併用療法を行った 3 例は 1 例で CR、2 例は 3rd line にCPT-11/NDP 療法を行ったが癌死であった。 有害事象は全例で骨髄抑制が認められたが、G-CSF 投与 を行い対処し重篤化する症例は認めなかった。【結語】新 規抗癌剂 TXL、CPT-11 を用いたサルベージ療法は難治 性精巣腫瘍に対する化学療法の 2nd line、3rd line として 有用性が期待される。

\section{OP-222化学療法抵抗性胚細胞腫瘍に対するエ ピルビシン、シスプラチン併用療法の 治療経験}

\footnotetext{
国立がんセンター中央病院乳腺・腫瘍内科”，国立がん センター中央病院泌尿器科2

米盛 勧 ${ }^{1}$, 河野 勤 ${ }^{1}$, 安藤 正志 ${ }^{1}$, 藤原 康弘 ${ }^{1}$ ， 込山 元清 ${ }^{22}$, 烊島 英二郎 ${ }^{2}$, 松岡 直樹 ${ }^{2}$, 藤元 博行 ${ }^{29}$ 背景 : 全身化学療法にも関わらず宽解が得られず、抵抗性と なった症例は難治症例となり、予後は極めて不良である。こ のような症例に対して、2005 年米国臨林腫瘍学会で Bedano PM らは Epirubicin + Cisplatin 併用療法 (EC)により 24 例中 $52 \%$ の奏功率と 5 例の 10 ケ月以上の長期生存例を認め、今 後期待される治療である可能性を報告した。目的：化学療法 抵抗性胚細胞腫韵に対する EC 療法の有効性と Feasibility について検討する。方法：2004 年 1 月から 2005 年 9 月まで 当院にて化学療法抵抗性胚細胞腫瘍に対して EC 療法 $(\mathrm{E}: 90$ $\mathrm{mg} / \mathrm{m} 2$, day $1, \mathrm{C}: 20 \mathrm{mg} / \mathrm{m} 2$, dayl-5, q3W）を実施した 4 例を レトロスペクティブに検討した。結果 : 効果は、PR : 2 例、 $\mathrm{SD}: 1$ 例、NE: 1 例であった。PR となった症例のうち 1 例は、 残存する肝転移病巣の切除術を実施し、腫場の残存は認めな かった。その後、約 10 ヶのの無病生存に至っている。治療中 止となる重篤な毒性を認めなかった。考察 : 少数例のレトロ スペクティブな检討であるが、 EC 療法は化学療法抵抗性症 例において 1 例の長期生存例を認め、治療も安全に実施でき ると判断できた為、第 II 相臨床試験を計画した。
}

\section{OP-223 精巣腫瘍旰転移の化学療法後の残存病 巣の管理}

\author{
筑波大学臨医泌尿器科学 \\ 河合 弘二, 及川 剖宏, 樋之津 史郎, 関户 哲利, \\ 宮永 直人, 島居 徹, 赤座 英之
}

【目的】精巣腫瘍肝転移例での化学療法後の残存病巣を中心 に臨床像を解析した。【方法】1986 年から 2005 年の間に筑 波大学で加療した肝転移例 12 例を対象とした。肝転移は単 発 5 例、多発 7 例であり、最大径の中央值は $5.4 \mathrm{~cm}(1-12$ $\mathrm{cm})$ であった。肝以外の転移巣としてはりンパ節又は肺転 移を 6 例、肺以外の臓器転移を 6 例に認めた。【成績】導入 化学療法としては BEP 療法が主に行われ、10 例では 2 次 以降の化学療法を必要とした。3例では腫瘍マーカーが正 常化せず癌死した。2 例では肝転移が完全消失し、2 例では 化学療法後にリンパ節郭清術と肝部分切除術（最大径 $1 \mathrm{~cm}$ 及び $2.2 \mathrm{~cm} ：$ い゙れも単発）が併施された。病理所見は 2 例とも壊死組織であったが 1 例は他臟器に再発し癌死し た。残り 5 例では腫愓マーカーの正常化後に残存肝転移巣 を経過観祭した。残存病巣はいずれも輁胞状であり、最大径 は $2.2 \mathrm{~cm}$ (中央值) で 3 例では複数残存した。 5 例中再発例 はなく、4例では治療終了後平均 37 ヶ月で残存病巣が消失 した。全体の長期成績としては 12 例中 8 例で寛解が得られ た (中央値 55 ケ月)。【結論】肝転移巣が残存した場合に経 過観察が可能な症例があることが示唆された。経過観察可 能な症例の選択基準に関しては今後の検討を必要とする。

\section{OP-224 当院不娃症例 1878 名中、治療後に精 巣腫瘍を発生した症例の検討}

\section{東北大学医学部泌尿器科学}

菅藤 哲, 高橋 勝治, 徳山 聡, 荒井 陽一

(背景) 近年スキャケケベックは停留精巣、尿道下裂、不弤、 精巣腫場は Genetic な原因或は内分泌加く乱物質への暴露 により胎児性腺が Testicular dysgenesis を起こすことを 共通の原因と報告した。そこで当院における不妊症症例と 精巣腫瘍症例を対象に雨者の関連を検討した。（対象と方 法） 1989 年から 2004 年までに不娃症及び精巣腫場にて治 療した症例につき検討した。精巣腫愓治療後に不妊を併発 した症例は対象から除外した。(結果) 当該期間中不妊を主 訴とした症例は 1878 名で、そのうちそ精子症 169 名、高度 乏精子症 117 名、無精子症 174 名であった。その中で 4 名に 後に精巣腫韵が発生した。 4 名中 2 名が初診時高度乏精子 症、1名が無精子症であった。無精子症の 1 例は異時性に両 側に腫瘍を発生した。高度乏精子症の 1 例に扔いて精巣腫 瘍発生前に ICSIにより挙児を得た。以上より高度乏精子症 の 117 名中 2 名 $(1.7 \%)$ 、無精子症の 174 名中 1 例 $(0.6 \%)$ に精巣腫黈が発生した。尚、不妊発生(結婚時或は結婚後避 娃終了時) 上り腫噋発生までの期間は 2 年から 11 年 (中央 値 6.5 年、平均値 5.2 年) であった。(考察) 高度乏精子症 は精巣腫嚎発生のリスクファクターとなっている可能性が 示唆された。また不妊治療終了後は精巣のセルフチェック を指導するなどの対策が必要と考えられた。 